\title{
KONSEP DASAR DAN TATA KELOLA MANAJEMEN PESERTA DIDIK \\ DI SEKOLAH
}

Zaedun Na'im

Dosen STAI Ma'had Aly Al-Hikam Malang

zaidun_naim@yahoo.com

\begin{abstract}
Abstrak
Di dunia pendidikan salah satu yang menjadi fokus perhatian dan sangat penting adalah peserta didik. Karena salah satu indikator bisa dikatakan keberhasilan penyelenggaraan pendidikan di sekolah adalah bisa di lihat dari prestasi peserta didik, sehingga sekolah perlu sekali memahami dan mendalami bagaimana memanage dan mengembangkan potensi dalam diri peserta didik
\end{abstract}

Oleh karenanya proses pendidikan yang bermutu akan menghasilkan lulusan yang bermutu dan relevan dengan pembangunan.

Pemahaman dan implementasi manajemen peserta didik sangat penting guna tercapainya cita-cita yang diinginkan oleh sekolah bisa tercapai, yakni keberhasilan peserta didik dalam menuntaskan apa yang sudah diprogramkan oleh sekolah.

Kata kunci: konsep dasar, tata kelola manajemen peserta didik.

\section{A. Latar Belakang}

Suatu sistem pendidikan dapat dikatakan bermutu jika proses belajar mengajarnya dapat berlangsung secara efektif dan efisien sehingga materi ajar yang akan disampaikan dapat sesuai dengan tujuan dan target yang 
telah ditetapkan. Proses pendidikan yang bermutu akan menghasilkan lulusan yang bermutu dan relevan dengan pembangunan. Dan untuk menghasilkan lulusan yang bermutu dalam hal ini tidak dapat terlepas dari bagaimana me-manage peserta didiknya. ${ }^{1}$

Di dunia pendidikan salah satu yang menjadi fokus perhatian dan sangat penting adalah peserta didik. Karena salah satu indikator bisa dikatakan keberhasilan pengelenggaraan pendidikan di sekolah adalah bisa di lihat dari prestasi peserta didik, sehingga sekolah perlu sekali memahami dan mendalami bagaimana memanage dan mengembangkan potensi dalam diri peserta didik. Sehingga di sekolah nantinya mampu mengembangkan kemampuan atau potensi yang dimiliki oleh peserta didik.

Peserta didik dalam UU Sisdiknas tahun 2003 adalah anggota masyarakat yang berusaha mengembangkan potensi diri melalui proses pembelajaran yang tersedia pada jalur, jenjang, dan jenis pendidikan tertentu ${ }^{2}$. Oleh karenanya sekolah diharapkan bisa menjalankan isi dari undang-undang tersebut agar tujuan yang diharapkan dari peserta didik bisa tercapai

Sebagai akibat dari adanya perbedaan bawaan peserta didik, maka akan ada peserta didik yang lambat dan ada peserta didik yang cepat perkembangannya. Kompetisi yang sehat akan memungkinkan jika ada usaha dan kegiatan manajemen, ialah manajemen peserta didik.

Demikian juga peserta didik yang bermasalah sebagai akibat dari adanya kompetisi akan dapat ditangani dengan baik manakala manajemen peserta didik-nya baik.Dalam upaya mengembangkan diri tersebut, ada banyak kebutuhan yang sering kali tarik-menarik dalam hal pemenuhan pemrioritasannya. Di satu sisi, para peserta didik ingin sukses dalam hal prestasi akademiknya, di sisi lain, ia ingin sukses dalam hal sosialisasi dengan sebayanya. Bahkan tidak itu saja, dalam hal mengejar

${ }^{1}$ Ahmad Ridlowi, Manajemen peserta didik ditinjau dari ruang lingkupnya. Diakses dalam http://aridlowi.blpgspot.com, 26 Agustus 2018

${ }^{2}$ UU Sisdiknas 2003.pasal 1 ayat 4

500 I KONSEP DASAR DAN TATA KELOLA MANAJEMEN PESERTA DIDIK

DI SEKOLAH 
keduanya, ia ingin senantiasa berada dalam keadaan sejahtera. Pilihanpilihan yang tepat atas ketiga hal yang sama-sama menarik tersebut, tidak jarang menimbulkan masalah bagi para peserta didik. Oleh karena itu diperlukan layanan tertentu yang dikelola dengan baik. manajemen peserta didik berupaya mengisi kebutuhan tersebut ${ }^{3}$

Berikut ini penulis paparkan bagaimana konsep dan tata kelola manajemen peserta didik di sekolah, sehingga bisa memberikan gambaran umum terkait manajemen peserta didik di sekolah.

\section{B. Pembahasan}

\section{Konsep manajemen peserta didik}

a. Pengertian manajemen

Ada beberapa pendapat yang mendefinisikan manajemen, sebagai berikut:

1) Secara stimologis, kata manajemen merupakan terjemahan dari management ( bahasa Inggris). Kata management sendiri berasal ari kata manage atau magiare yang berarti melatih kuda dalam melangkahkan kakinya. Dalam pengertian manajemen, terkandung dua kegiatan ialah kegiatan berpikir (mind) dan kegiatan tingkahlaku ( action). (Sahertian, 1982)

2) Manajemen adalah penggunaan efektif sumber-sumber tenaga manusia dan bukan manusia serta bahan material lainnya dalam rangka mencapai tujuan yang telah ditentukan (B. Suryobroto, manajemen pendidikan di sekolah)

3) Menurut H. Malayu S.P. Hasibuan, manajemen adalah ilmu dan seni mengatur proses pemanfaatan sumber daya manusia dan sumber-sumber lainnya secara efektif dan efesien untuk mencapai suatu tujuan tertentu

Roisyiah. KONSEP DASAR MANAJEMEN PESERTA DIDIK. Diakses dalam https://putrisritanjungunior.wordpress.com/category/roisyiah, 26 Agustus 2018 
EVALUASI. Vol 2. No.2, September 2018 P-ISNN 2580-3387

E-ISSN 2615-2886

4) The Liang Gie (1978) memberikan batasana manajemen sebagai segenap perbuatan menggerakkan sekelompok orang atau mengarahkan segala fasilitas dalam sutau usaha kerjasama untuk mencapai tujuan tertentu. ${ }^{4}$

Masih banyak lagi pakar pendidikan yang mendefiniskan manajemen, namun penulis hanya menyebutkan beberapa pandapat saja yang penulis anggap sudah bisa mewakili pendapat yang lainnya.

Dari beberapa pendapat diatas dapat disimpiulkan bahwa manajemen adalah suatu ilmu yang mengatur agar sumber daya yang dimiliki bisa betrjalan dengan optimal sesuai dengan tujuan yang diharapkan.

b. Peserta didik

Ada beberapa pendapat yang mendefiniskan peserta didik, antara lain:

1) Peserta didik menurut ketentuan umum undang-undang $\mathrm{RI}$ no. 20 tahun 2003 tentang sistem pendidikan nasional adalah anggota masyarakat yang berusaha mengembangkan potensi diri melalui proses pembelajaran yang tersedia pada jalur, jenjang, dan jenis pendidikan tertentu.

2) Peserta didik merupakan suatu komponen masukan dalam system pendidikan, yang selanjutnya di proses dalam pendidikan, sehingga menjadi manusia yang berkualitas sesuai dengan tujuan pendidikan nasional ( oemar Hamalik, Kurikulum dan pembelajaran)

3) Peserta didik adalah sosok manusia sebagai individu atau pribadi manusia seutuhnya. Individu diartikan " seseorang tidak tergantung dari orang lain, dalam arti benar-benar seorang pribadi yang

\footnotetext{
${ }^{4}$ Eka prihatin. Manajemen Peserta Didik. Cet 2 (Bandung; Alfabeta, 2014) hlm 2
}

502 I KONSEP DASAR DAN TATA KELOLA MANAJEMEN PESERTA DIDIK DI SEKOLAH 
mennetukan diri sendiri dan tidak dipaksa dari luar, mempunyai sifatsifat dan keinginan sendiri ( Abu Ahmadi, 2001:39)

Dari beberapa pendapat di atas dapat disimpulkan, bahwa peserta didik adalah orang atau individu yang diproses melalui pendidikan, sehingga bisa dikembangkan potensi dalam dirinya serta sesuai dengan tujuan pendidikan nasional

c. Pengertian manajemen peserta didik

Ada beberapa defiisi tentang manajemen peserta didik, antara lain:

1) Manajemen peserta didik sebagai layanan yang memusatkan perhatian pada pengaturan, pengawasan, dan layanan sisiwa di kelas dan di luar kelas seperti: pengenalan, pendaftaran, layanan individual seperti pengembangan keseluruhan kemampuan, minat, kebutuhan sampai ia matang di sekolah ( Knezevich, 1961)

2) Manajemen peserta didik dapat diartikan sebagai usaha pengaturan terhadap peserta didik mulai dari peserta didik tersebut masuk sekolah sampai dengan mereka lulus sekolah

3) Manajemen peserta didik adalah suatu penataan atau pengaturan segala aktivitas yang berkaitan dengan peserta didik, yaitu dari mulai masuknya peserta didik sampai dengan keluarnya peserta didik tersebut dari suatu sekolah atau suatu lembaga ( Hendayat Soetopo dan Wasty Soemanto, 1982) ${ }^{6}$

Dari beberapa pendapat diatas dapat disimpulkan bahwa manajemen peserta didik adalah usaha pengaturan yang berkenaan dengan peserta didik, baik ketika awal masuk sekolah sampai dengan lulusnya peserta didik

d. Tujuan dan fungsi manajemen peserta didik

\footnotetext{
${ }^{5}$ Eka Prihatin op.cit hlm 3

${ }^{6}$ Ibid hlm 4
} 
Tujuan umum manajemen peserta didik adalah: mengatur kegiatan-kegiatan peserta didik agar kegiatan-kegiatan tersebut menunjang proses belajar mengajar di sekolah; lebih lanjut, proses belajar mengajar di sekolah dapat berjalan lancar, tertib dan teratur sehingga dapat memberikan kontribusi bagi pencapaian tujuan sekolah dan tujuan pendidikan secara keseluruhan.

Tujuan khusus manajemen peserta didik adalah sebagai berikut:

1) Meningkatkan pengetahuan, keterampilan dan psikomotor peserta didik.

2) Menyalurkan dan mengembangkan kemampuan umum (kecerdasan), bakat dan minat peserta didik.

3) Menyalurkan aspirasi, harapan dan memenuhi kebutuhan peserta didik.

Dengan terpenuhinya 1,2 , dan 3 di atas diharapkan peserta didik dapat mencapai kebahagiaan dan kesejahteraan hidup yang lebih lanjut dapat belajar dengan baik dan tercapai cita-cita mereka.

Fungsi manajemen peserta didik secara umum adalah: sebagai wahana bagi peserta didik untuk mengembangkan diri seoptimal mungkin, baik yang berkenaan dengan segi-segi individualitasnya, segi sosialnya, segi aspirasinya, segi kebutuhannya dan segi-segi potensi peserta didik lainnya.

Fungsi manajemen peserta didik secara khusus dirumuskan sebagai berikut:

a) Fungsi yang berkenaan dengan pengembangan individualitas peserta didik, ialah agar mereka dapat mengembangkan potensipotensi individualitasnya tanpa banyak terhambat. Potensipotensi bawaan tersebut meliputi: kemampuan umum (kecerdasan), kemampuan khusus (bakat), dan kemampuan lainnya.

\title{
504 I KONSEP DASAR DAN TATA KELOLA MANAJEMEN PESERTA DIDIK
}

\author{
DI SEKOLAH
}


b) Fungsi yang berkenaan dengan pengembangan fungsi sosial peserta didik ialah agar peserta didik dapat mengadakan sosialisasi dengan sebayanya, dengan orang tua dan keluarganya, dengan lingkungan sosial sekolahnya dan lingkungan sosial masyarakatnya. Fungsi ini berkaitan dengan hakekat peserta didik sebagai makhluk sosial.

c) Fungsi yang berkenaan dengan penyaluran aspirasi dan harapan peserta didik, ialah agar peserta didik tersalur hobi, kesenangan dan minatnya. Hobi, kesenangan dan minat peserta didik demikian patut disalurkan, oleh karena ia juga dapat menunjang terhadap perkembangan diri peserta didik secara keseluruhan.

d) Fungsi yang berkenaan dengan pemenuhan kebutuhan dan kesejahteraan peserta didik ialah agar peserta didik sejahtera dalam hidupnya. Kesejahteraan demikian sangat penting karena dengan demikian ia akan juga turut memikirkan kesejahteraan sebayanya. $^{7}$

\section{e. Prinsip-prinsip manajemen peserta didik}

Yang dimaksudkan dengan prinsip adalah sesuatu yang harus dipedomani dalam melaksanakan tugas. Jika sesuatu tersebut sudah tidak dipedomani lagi, maka akan tanggal sebagai suatu prinsip. Prinsip manajemen peserta didik mengandung arti bahwa dalam rangka memanage peserta didik, prinsip-prinsip yang disebutkan di bawah ini haruslah selalu dipegang dan dipedomani. Adapun prinsipprinsip manajemen peserta didik tersebut adalah sebagai berikut:

1) Manajemen peserta didik dipandang sebagai bagian dari keseluruhan manajemen sekolah. Oleh karena itu, ia harus mempunyai tujuan yang sama dan atau mendukung terhadap tujuan manajemen secara keseluruhan. Ambisi sektoral manajemen peserta didikB tetap ditempatkan dalam kerangka

\footnotetext{
${ }^{7}$ Akhmad Sudrajat. Konsep dasar manajemen peserta didik diakses dalam https://akhmadsudrajat.wordpress.com/author/akhmadsudrajat, 26 Agustus 2018
} 
manajemen sekolah. la tidak boleh ditempatkan di luar sistem manajemen sekolah.

2) Segala bentuk kegiatan manajemen peserta didik haruslah mengemban misi pendidikan dan dalam rangka mendidik para peserta didik. Segala bentuk kegiatan, baik itu ringan, berat, disukai atau tidak disukai oleh peserta didik, haruslah diarahkan untuk mendidik peserta didik dan bukan untuk yang lainnya.

3) Kegiatan-kegiatan manajemen peserta didik haruslah diupayakan untuk mempersatukan peserta didik yang mempunyai aneka ragam latar belakang dan punya banyak perbedaan. Perbedaanperbedaan yang ada pada peserta didik, tidak diarahkan bagi munculnya konflik di antara mereka melainkan justru mempersatukan dan saling memahami dan menghargai.

4) Kegiatan manajemen peserta didik haruslah dipandang sebagai upaya pengaturan terhadap pembimbingan peserta didik. Oleh karena membimbing, haruslah terdapat ketersediaan dari pihak yang dibimbing. Ialah peserta didik sendiri. Tidak mungkin pembimbingan demikian akan terlaksana dengan baik manakala terdapat keengganan dari peserta didik sendiri.

5) Kegiatan manajemen peserta didik haruslah mendorong dan memacu kemandirian peserta didik. Prinsip kemandirian demikian akan bermanfaat bagi peserta didik tidak hanya ketika di sekolah, melainkan juga ketika sudah terjun ke masyarakat. Ini mengandung arti bahwa ketergantungan peserta didik haruslah sedikit demi sedikit dihilangkan melalui kegiatan-kegiatan manajemen peserta didik.

6) Apa yang diberikan kepada peserta didik dan yang selalu diupayakan oleh kegiatan manajemen peserta didik haruslah fungsional bagi kehidupan peserta didik baik di sekolah lebih-lebih di masa depan. ${ }^{8}$

f. Pendekatan manajemen peserta didik

(Yuager,1949) yang dikutip oleh Ali Imron (2004), mengemukakan bahwa ada dua pendekatan yang digunakan dalam

${ }^{8}$ Akhmad Sudrajat ibid

506 I KONSEP DASAR DAN TATA KELOLA MANAJEMEN PESERTA DIDIK

DI SEKOLAH 
manajemen peserta didik yaitu pendekatan kuantitatif (the quantitative approach) dan pendekatan kualitataif (the quantitative approach)

Pendekatan kuantitatif menitikberatkan pada segi administrative dan birokratik lembaga pendidikan, dimana peserta didik diharapkan memenuhi segala tuntutan dan harapan lembaga pendidikan dengan asumsi bahwa apabila peserta didik memenuhi segala aturan, tugas dan harapan yang diinginkan oleh lembaga pendidikan maka akan menjadikan peserta didik yang berjiwa matang dan tercapai segala harapannya.

Sedangkan pendekatan kualitatif menitikberatkan pada kesejahteraan peserta didik dengan asumsi bahwa jika peserta didik senang dan sejahtera, maka mereka dapat belajar dengan baik dan merasa senang untuk mengembangkan diri di sekolah. Pendekatan ini menekankan pada perlunya lingkungan yang kondusif dan menyenangkan bagi pengembangan diri secara optimal. ${ }^{9}$

g. Ruang lingkup manajemen peserta didik

Secara umum manajemen kesiswaan atau manajemen peserta didik sedikitnya memiliki tiga tugas utama yang harus diperhatikan, yaitu penerimaan murid baru, kegiatan kemajuan belajar, serta bimbingan dan pembinaan disiplin. Secara rinci, ruang lingkup peserta didik adalah sebagai berikut: ${ }^{10}$

\section{1). Perencanaan Peserta Didik}

Langkah pertama yang harus dilakukan dalam manajemen kesiswaan yaitu mengadakan perencanaan. Peserta didik harus direncanakan, karena dengan adanya perencanaan segala sesuatunya dapat dipikirkan dengan matang. Dengan demikian, masalah-masalah yang muncul akan dapat ditangani sesegera mungkin.

${ }^{9}$ Eka Prihatin. Op.cit hlm 12

${ }^{10}$ Lilis Maryati. Manajemen Peserta Didik. Diakses dalam http://lilisaryanti.blogspot.com, 26 Agustus 2018 
2). Penerimaan Peserta Didik Baru

Penerimaan peserta didik baru adalah salah satu kegiatan manajemen peserta didik yang sangat penting. Dalam penerimaan peserta didik baru ini meliputi beberapa tahapan, yaitu (1) kebijaksanaan penerimaan peserta didik, (2) system penerimaan peserta didik, (3) kriteria penerimaan peserta didik baru, (4) prosedur penerimaan peserta didik baru, dan (5) problema penerimaan peserta didik baru.

3). Orientasi Peserta Didik

Peserta didik yang sudah melakukan daftar ulang, mereka kemudian akan memasuki masa orientasi peserta didik di sekolah. orientasi ini dilakukan dari hari-hari pertama masuk sekolah. Pada bagian ini secara berurutan terdiri dari (1) alasan dan batasan orientasi peserta didik, (2) tujuan dan fungsi orientasi peserta didik, (3) hari-hari pertama di sekolah, (4) pecan orientasi peserta didik.

4). Mengatur Kehadiran dan Ketidakhadiran Peserta Didik

Kehadiran peserta didik di sekolah sangat penting, karena jika peserta didik tidak hadir di sekolah, tentu aktivitas belajar mengajar di sekolah tidak dapat dilaksanakan. Kehadiran peserta didik di sekolah adalah suatu kondisi yang memungkinkan terjadinya interaksi belajar mengajar.

5). Pengelompokan Peserta Didik

Peserta didik yang sudah melakukan daftar ulang, mereka perlu dikelompokkan atau diklasifikasikan. Pengklasifikasian diperlukan bukan dimaksudkn untuk mengotak-kotakkan peserta didik, tetapi justru dimaksudkan untuk membantu keberhasilan mereka. Kegiatan yang termasuk dalam bagian ini yaitu (1) urgensi pengelompokan, (2) wacana pengelompokan, (3) jenis-jenis pengelompokan, dan (4) pengelompokan dan penjurusan.

\title{
508 I KONSEP DASAR DAN TATA KELOLA MANAJEMEN PESERTA DIDIK
}

\author{
DI SEKOLAH
}


6). Mengatur Evaluasi Hasil Belajar Peserta Didik

Evaluasi hasil belajar terhadap peserta didik sangat perlu dilakukan, agar diketahui perkembangan mereka dari waktu ke waktu. Evaluasi hasil belajar peserta didik dimaksudkan untuk mengetahui sejauh mana peserta didik telah dapat menampilkan performa sesuai yang diharapkan. Kegiatan yang termasuk dalam bagian ini yaitu, (1) alasan perlunya evaluasi hasil belajar peserta didik, (2) batasan evaluasi hasil belajar peserta didik, (4) teknik-teknik evaluasi hasil belajar peserta didik, (5) kriteriakriteria evaluasi hasil belajar peserta didik, (6) tindak lanjut evaluasi hasil belajar peserta didik.

7). Mengatur Kenaikan Tingkat Peserta Didik

Kenaikan kelas dapat diatur sesuai dengan kebijakan dari msingmasing sekolah. Dalam kenaikan kelas sering terjadi masalahmasalah yang memerlukan penyelesaian secara bijak. Masalah ini dapat diperkecil jika data-data tentang hasil evaluasi siswa obyektif dan mendayagunakan fungsi. Juga para guru harus berhati-hati dalam memberikan nilai hasil evaluasi belajar kepada siswa.

8). Mengatur Peserta Didik yang Mutasi dan Drop Out

Mutasi dan drop out seringkali membawa masalah di dunia pendidikan. Oleh karena itu, keduanya harus ditangani dengan baik, agar tidak mengakibatkan keruwetan dan keribetan yang berlarut-larut, sehingga pada akhirnya akan mengganggu aktivitas sekolah secara keseluruhan.

9). Kode Etik, Pengadilan, Hukuman dan Disiplin Peserta Didik

Pendidikan disini didasarkan atas norma-norma tertentu bagi peserta didik. Norma-norma dan aturan-aturan tersebut, mengharuskan peserta didik untuk mengikutinya. Selain itu, para pendidik selayaknya juga menjadi contoh terdepan dalam dalam hal pentaatan terhadap tradisi dan aturan yang dikembangkan di lembaga pendidikan. 
2. Tata laksana manajemen peserta didik

a. Pengertian

Terdapat beberapa komponen yang sangat penting untuk mendukung peningkatan keberhasilan penyelenggaraan pendidikan dan salah satunya yang pokok tersebut adalah penyelenggaraan manajemen pendidikan yang dalam lingkup mikro disebut juga manajemen sekolah ${ }^{11}$

Dalam manajemen sekolah yang lebih spesifik lagi pembahasannya adalah manajemen peserta didik. Jadi yang dikehendaki dalam tata kelola manajemen peserta didik berarati bagaimana cara pengelolaan yang baik dalam memanage peserta ddik sehingga penyelenggaraan pendidikan bisa bermutu sesuai dengan tujuan yang diiinginkan

Dalam konteks pendidikan pengertian mutu mencakup input,proses, dan out put pendidikan. ${ }^{12}$

1) Input pendidikan adalah segala sesuatu yang harus tersedia karena dibutuhkan untuk berlangnya proses.

Input sumber daya meliputi sumber daya manusia ( kepala sekolah, guru termasuk guru BP, karyawan, siswa) dan sumber-sumber selebihnya ( peralatan, perlengkapan, uang, bahan, dsb). Input perangkat lunak meliputi struktur organisasi sekolah, peraturan perundang-undangan, deskrispsi tugas, rencana, program, dsb

2) Proses pendidikan merupakan berubahnya sesuatu menjadi sesutau yang lain.

Proses dikatakan bermutu dikatakan bermutu tinggi apabila pengkoordinasian dan penyerasian serta pemaduan input

\footnotetext{
${ }^{11}$ Eka Prihatin op.cit hlm 185

${ }^{12}$ Ibid hlm 187
}

510 I KONSEP DASAR DAN TATA KELOLA MANAJEMEN PESERTA DIDIK

DI SEKOLAH 
EVALUASI. Vol 2. No.2, September 2018 P-ISNN 2580-3387

E-ISSN 2615-2886

sekolah (guru, siswa, kurikulum, uang, peralatan dan sebagainya)

3) Out pendidikan adalah merupakan kinerja sekolah.

Kinerja sekolah adalah prestasi sekolaah yang dihasilkan dari proses / perilaku sekolah. Kinerja sekolah dapat diukur dari kualitasnya, efektivitasnya, produktivitasnya, efesiensinya, inovasinya, kualitas kehidupan kerjanya dan moral kerjanya

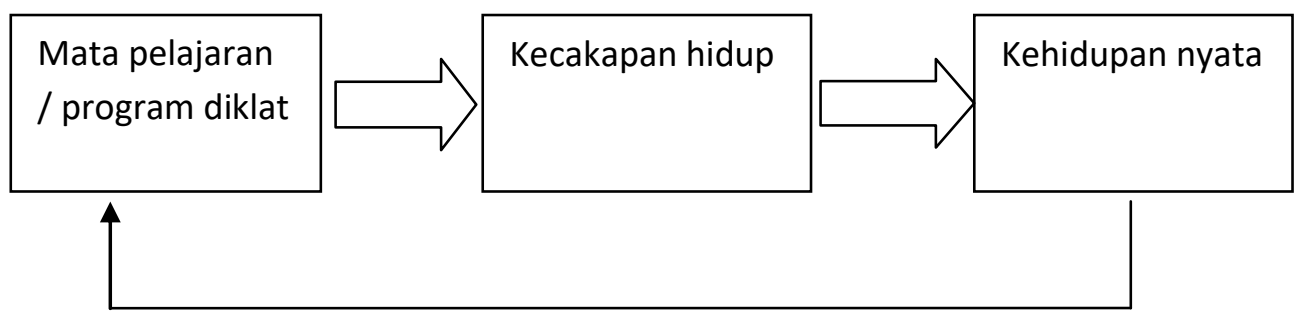

Hubungan antara mata pelajaran, life skill dan kehidupan nyata

b. Manfaat penyusunan rencana

Sebuah rencana dibuat untuk kemudian dilaksanakan, maka penyusunannya harus mengingat beberapa patokan atau pedoman utama, yakni:

1) Kemampuan

2) Kondisi dan situasi

3) Tanggung jawab

4) Kerjasama

Persencanaan harus disesuaikan dengan kemampuan yang ada: sumber-sumber yang tersedia, kemampuan tenaga pelaksana, sumber keuangan, bahan-bahan yang dimiliki, dan sebagainya. Sebuah rencana yang dibuat tanpa mengingat 
EVALUASI. Vol 2. No.2, September 2018 P-ISNN 2580-3387

E-ISSN 2615-2886

kemampuan untuk mencapainya, maka mudah kandas di tengah jalan. $^{13}$

Hal ini menunjukkan betapa besar manfaat sebuah perencanaan yang disusun dengan sistematis dan seksama, sehingga apa yang diharapkan bisa berjalan dengan lancar dan berhasil

Faktor yang harus menjadi pertimbangan dalam membuat perencanaan, maka sebuah rencana yang baik harus memiliki sifat-sifat:

a) Rasional, artinya rencana dibuat berdasarkan pemikiran dan perhitungan yang masak, sesuai dengan kemampuan yang ada

b) Luwes, atau fleksibel, artinya rencana dapat mudah menyesuaikan diri dengan perbuhan/perkembangan situasi dan kondisi yang mungkin terjadi. ${ }^{14}$

c. Macam-macam pelaksanaan perencanaan

Suatu pelaksanaan perencanaan dapat dilihat dari empat sudut pandangan, yaitu:

1) Tingkatan manajemen

Dari sudut tingkatan manajemen, ada beberapa macam jenis perencanaan:

a).Perencanaan kebijaksanaan dasar (policy planning atau administrative planning), adalah perencanaan yang memuat tentang garis besar kebijaksanaan (policy) dari seluruh kegiatan organiasi. Perencanaan kebijaksanaan

${ }^{13}$ Eka Prihatin op.cit hlm 187

${ }^{14}$ ibid

512 I KONSEP DASAR DAN TATA KELOLA MANAJEMEN PESERTA DIDIK

DI SEKOLAH 
EVALUASI. Vol 2. No.2, September 2018 P-ISNN 2580-3387

E-ISSN 2615-2886

dasar ini dibuat oleh pimpinan pada tingkatan top management atau manajemen puncak

b).Perencanaan program (program planning atau managerial planning), adalah perencanaan untuk menterjemahkan kebijaksanaan dasar tersebut ke dalam program-program untuk dilaksanakan.perencanaan program disusun oleh piminan atau manajemen tengah

c). Perencanaan operasional (operational planning), adalah perencanaan pada tingkat terakhir yang dibuat oleh pimpinan tingkat rendah atau tingkat pertama untuk melaksanakan program kerja di lapangan.

2) Jangka waktu

Dari sudut masa berlakunya sebuah rencana, atau berdasarkan tahapannya, ada beberapa macam jenis perencanaan:

a). perencanaan jangka pendek, yang biasanya berlaku dalam satu, dua, tiga, empat, dan lima tahun

b) perencanaan jangka pajang, yang biasanya dibuat untuk jangka waktu 10 tahun atau lebih

c). perencanaan tahunan, yang dibuat untuk satu tahun dna merupakan program pelaksanaan dari pada perencanaan jangka pendek.

3) Daerah berlakunya

Berdasarkan daerah berlakunya, kita mengenal perencanaan yang dibuat secara internasional ( antar bangsa), nasional ( di dalam sebuah Negara), regional ( antar wilayah), dan lokah ( daerah)

4) Materi perencanaan 
EVALUASI. Vol 2. No.2, September 2018 P-ISNN 2580-3387

E-ISSN 2615-2886

Berdasarkan materi perencanaan, kita mengenal bidangbidang seperti: perencanaan keamanan dan ketertiban, pendidikan, industri, kebudayaan, perdagangan, keuangan, tata kota, dan sebagainya. Yang juga termasuk di dalam pembuatan rencana, tetapi adakalanya dipisahkan menjadi bab tersendiri, adalah masaaah-masalah penyusunan budget ( biaya), standard, dan program atau cara kerja.

Sehingga secara lebih luas lagi sesungguhnya perencanaan dapat dirumuskan sebagai penetapan tujuan, kebijaksanaan dasar, prosedur, budget, standard, dan program dari suatu organisasi

Adapun kegiatannya meliputi: menetapkan peraturanperaturan dan pedoman-pedoman pelaksanaan tugas, menetapkan biaya dan pemasukan yang diharapkan serta rangkaian tindakan yang akan dilakukan di masa depan ${ }^{15}$

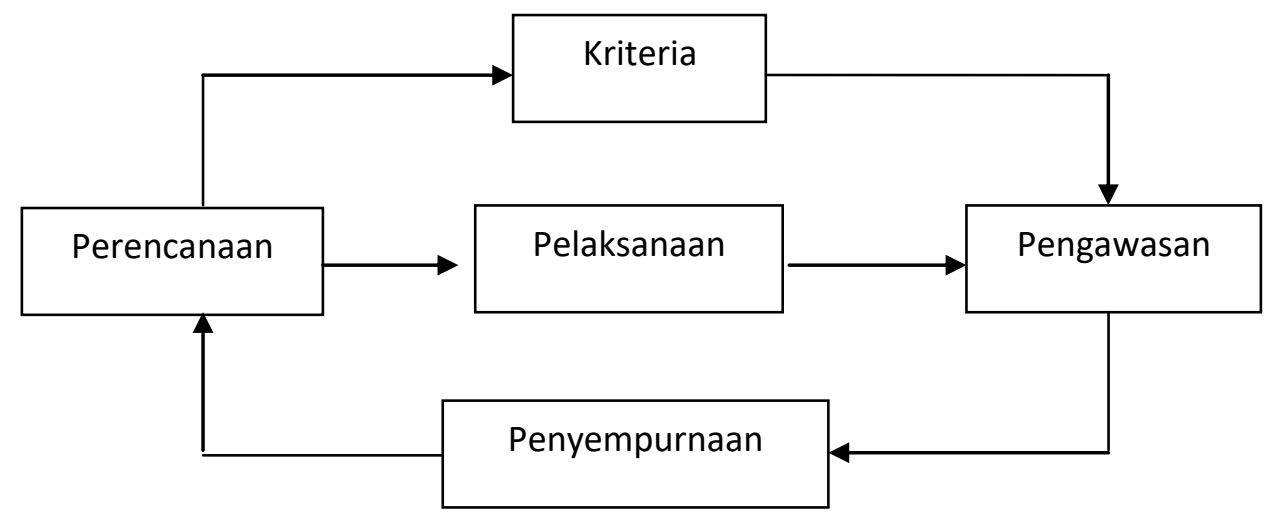

Gambaran pelaksanaan perencanaan

${ }^{15}$ Eka Prihatin.ibid hlm 190-191

514 I KONSEP DASAR DAN TATA KELOLA MANAJEMEN PESERTA DIDIK DI SEKOLAH 
EVALUASI. Vol 2. No.2, September 2018 P-ISNN 2580-3387

E-ISSN 2615-2886

d. Instrument tata laksana manajemen peserta didik

Dalam melakukan pencataan dan pelaporan kemajuan peserta didik diperlukan beberapa peralatan dan perlengkapan berupa:

1) Buku induk, disebut juga buku pokok atau stambuk, buku ini berisi catatan tentang peserta didik yang masuk pada sekolah tersebut.

2) Buku kleper, pencatatan buku ini dapat diambil dari buku induk, tetapi penulisannya disusun berdasarkan abjad, dan hal itu tujuannya adalah untuk memudahkan pencarian data peserta didik kembali jika sewaktu-waktu diperlukan

3) Daftar presensi adalah dafar hadir peserta didik sangat penting sebab frekuensi kehadiran peserta didik dapat diketahui atau dikontrol.

4) Daftar mutasi peserta didik, untuk mengetahui keadaan jumlah peserta didik dengan tepat, sehingga sekolah harus mempunyai buku atau daftar mutasi peserta didik. Daftar mutasi ini digunakan untuk menata keluar masuk peserta didik dalam setiap bulan, semester atau tahunan.

5) Daftar catatan pribadi peserta didik. Buku catatan ini isinya lebih lengkap lagi tentang data peserta didik, berisi: identitas peserta didik, keterangan mengenai keadaan keluarga, keadaaan jasmani dan kesehatan, riwayat pendidikan serta hasil belajar, data psikologis (sikap, minat dan cita-cita) dan juga kegiatan di luar sekolah.

6) Daftar nilai, daftar ini dimiliki oleh setiap guru bidang studi, khusus untuk mencatat hasil test setiap peserta didik pada bidang studi atau mata pelajaran tertentu

7) Lengger merupakan kumpulan nilai dari seluruh bidang studi untuk setiap peserta didik. Pengisian atau pencatatan nilainilai pada lengger ini dikerjakan oleh wali kelas sebagai bahan pengisian rapot 
8) Buku rapor, merupakan alat untuk melaporkan prestasi belajar peserta didik kepada orangtua atau wali atau kepada peserta didik itu sendiri. Selain prestasi belajar, dilaporkan pula tentang kehadiran, tingkah laku peserta didik dan sebagainya. ${ }^{16}$

Semua buku atau daftar tersebut saling melengkapi dan berubungan satu sama lain. Dengan demikian diharapkan dapat tercacat semua aspek yang diperlukan mengenai segala hal yang berhubungan dengan peserta didik.

\section{Penutup}

Dari uraian diatas dapat disimpulkan:

1. Manajemen peserta didik adalah usaha pengaturan yang berkenaan dengan peserta didik, baik ketika awal masuk sekolah sampai dengan lulusnya peserta didik.

2. Tujuan umum manajemen peserta didik adalah: mengatur kegiatan-kegiatan peserta didik agar kegiatan-kegiatan tersebut menunjang proses belajar mengajar di sekolah; lebih lanjut, proses belajar mengajar di sekolah dapat berjalan lancar, tertib dan teratur sehingga dapat memberikan kontribusi bagi pencapaian tujuan sekolah dan tujuan pendidikan secara keseluruhan.

3. Tujuan umum manajemen peserta didik adalah: mengatur kegiatan-kegiatan peserta didik agar kegiatan-kegiatan tersebut menunjang proses belajar mengajar di sekolah; lebih lanjut, proses belajar mengajar di sekolah dapat berjalan lancar, tertib dan teratur

4. Fungsi manajemen peserta didik secara umum adalah: sebagai wahana bagi peserta didik untuk mengembangkan diri seoptimal mungkin, baik yang berkenaan dengan segi-segi individualitasnya,

${ }^{16}$ Eka prihatin op.cit hlm 194-195

\section{I KONSEP DASAR DAN TATA KELOLA MANAJEMEN PESERTA DIDIK}

DI SEKOLAH 
EVALUASI. Vol 2. No.2, September 2018 P-ISNN 2580-3387

E-ISSN 2615-2886

segi sosialnya, segi aspirasinya, segi kebutuhannya dan segi-segi potensi peserta didik lainnya

5. Ruang lingkup manajemen pendidikan peserta didik, antara lain:

a. Perencanaan Peserta Didik

b. Penerimaan Peserta Didik Baru

c. Orientasi Peserta Didik

d. Mengatur Kehadiran dan Ketidakhadiran Peserta Didik

e. Pengelompokan Peserta Didik

f. Mengatur Evaluasi Hasil Belajar Peserta Didik

g. Mengatur Kenaikan Tingkat Peserta Didik

h. Mengatur Peserta Didik yang Mutasi dan Drop Out

i. Kode Etik, Pengadilan, Hukuman dan Disiplin Peserta Didik

6. Insrumen tata laksana manajemen peserta didik, antara lain:
a. Buku induk
b. Buku kleper
c. Daftar presensi
d. Daftar mutasi peserta didik
e. Daftar catatan pribadi peserta didik
f. Daftar nilai
g. Lengger
h. Buku rapor 
EVALUASI. Vol 2. No.2, September 2018 P-ISNN 2580-3387

E-ISSN 2615-2886

\section{Daftar Rujukan}

Maryati, Lilis. Manajemen Peserta Didik. Diakses dalam http://lilisaryanti.blogspot.com.

Ridlowi, Ahmad, Manajemen peserta didik ditinjau dari ruang lingkupnya. Diakses dalam http://aridlowi.blpgspot.com.

Roisyiah. KONSEP DASAR MANAJEMEN PESERTA DIDIK. Diakses dalam https://putrisritanjungunior.wordpress.com/category/roisyiah.

Prihatin Eka. 2014. Manajemen Peserta Didik. Cet 2 (Bandung; Alfabeta)

Sudrajat, Akhmad. Konsep dasar manajemen peserta didik. diakses dalam https://akhmadsudrajat.wordpress.com/author/akhmadsudrajat.

UU Sisdiknas 2003. 